\title{
Treatment of Organic Compounds of Landfill Leachate in Vietnam by Combining Coagulation and Ozonation Process
}

\author{
${ }^{1}$ Van Huu Tap and ${ }^{2}$ Trinh Van Tuyen \\ ${ }^{1}$ Division of Environmental Technology, Faculty of Environment and Earth Sciences, \\ Thai Nguyen University of Sciences (TNUS), Vietnam \\ ${ }^{2}$ Department of Treatment of Solid Waste and Air Pollution, \\ Institute of Environmental Technology, Vietnam Academy of Science and Technology (VAST), Vietnam
}

Received 2013-07-17; Revised 2013-07-30; Accepted 2014-01-20

\begin{abstract}
Landfill leachate is a problematic pollution that should be solved in Viet Nam. This study presents some experimental results of removals of COD and color from landfill leachate by using coagulation and ozonation processes to determine the optimal reaction conditions. In pre-treatment stage by coagulation, the results showed that the removals obtained from three types of coagulants showed a maximum at the concentration of more than $3,000 \mathrm{mg} \mathrm{L}^{-1}$ under the $\mathrm{pH}$ region from 7 to 8 . The results also indicated that the significant removals of COD and color were obtained at the concentration of $1,500 \mathrm{mg} \mathrm{L}^{-1}$ and that PAC was the most suitable coagulant for the pre-treatment stage. The removals of COD and color in the pretreatment stage were approximately 30 and $70 \%$, respectively. Ozonation process was applied to leachate after coagulation. The experiments are done with effective of $\mathrm{pH}$ between 5 and 10 , reaction time between 20 and $120 \mathrm{~min}$ and the amount of COD between 3 and $12 \mathrm{~kg}$. The optimum pH at ozonation was 8 and the highest removals of COD and color were 57 and $80 \%$, respectively. In addition, the optimal reaction time and the amount of COD were $60 \mathrm{~min}$ and $3 \mathrm{~kg}$, respectively.
\end{abstract}

Keywords: Landfill Leachate, Coagulant, Ozonation, COD, Color

\section{INTRODUCTION}

Currently, solid wastes generated in urban areas in Vietnam are not classified and treated thoroughly. Leachate generated from landfill sites is not controlled and treated properly. Landfill leachate is a very complex wastewater in Vietnam. There are several toxic components of solid waste such as batteries, engine oil, chemicals, toxic waste in industry, commerce, hospital which can carry heavy metals and other toxic organic compounds out leachate.

Landfill sites have generated the large amount of leachate containing highly toxic and nonbiodegradable organic matters, bad odour and gray color (Tung et al., 2009). If leachate is not properly treated, it will pollute surface and ground water, causing serious environmental contamination. It is a challenge to environmental scientists.

The use of ozonation process to treat landfill leachate will have high performance because ozone oxidizes strongly organic compounds in the leachate. However, because of its high pollution levels, leachate needs to be pre-treated to reduce the amount of organic compounds. Rosario et al. (2011) used ozone to treat landfill leachate, after the application for $60 \mathrm{~min}$ of ozone at $5.6 \mathrm{~g} \mathrm{O}^{-1} \mathrm{~h}^{-1}$, initial $\mathrm{pH} 7$ and $400 \mathrm{mg} \mathrm{L}^{-1}$ of hydrogen peroxide, COD removal efficiency was $72 \%$ and $\mathrm{BOD}_{5} / \mathrm{COD}$ increased from 0.01 to 0.24 . Advanced Oxidation Processes (AOPs) were used to oxidise organic matters in wastewater (Malato et al., 2011; Zhou et al., 2009). According to Aken et al. (2011), the oxidation with an ozone dosage of $1.3 \mathrm{~g} \mathrm{O}_{3} \mathrm{~g}^{-1} \mathrm{COD}$ in $2 \mathrm{~h}$ and $\mathrm{pH}$ value of Thai Nguyen University of Sciences (TNUS), Vietnam 
9 achieved COD reduction of $30 \%$. Other reaction time and $\mathrm{pH}$ values were not determined with their research. COD removal reached up $70 \%$ for $240 \mathrm{~g} \mathrm{O}_{3} \mathrm{~L}^{-1}$ of leachate. The percentages for COD and colour removals at ozone dosage of $400 \mathrm{mg} \mathrm{L}^{-1} \mathrm{~h}^{-1}$ and $\mathrm{pH}$ of 9 were found to be 50 and $90 \%$, respectively (Ratanatamskul and Auesuntrachun, 2009).

The objective of this research investigate the application of coagulation and ozonation process to remove both COD and color from leachate of landfill sites in Vietnam. These processes reduce part of the persistent organic matters in leachate. Coagulated leachate was then oxidized by ozone to break down the chemical links of organic matters in landfill leachate. In the part, there were many researchs of landfill leachate treatment based on ozone but not researching enough effects of all condition $(\mathrm{pH}$, reaction time, ozone dosage and the amount of COD...). Some researchers focused on high $\mathrm{pH}$ and only ozone dosage to treat landfill leachate or only treatment by ozonation process. There is not researcher focusing on the amount of COD to assess COD and color removal. Therefore, in this research, all effects of factors on coagulation and ozonation process are considered to treat organic materials of leachate.

\section{MATERIALS AND METHODS}

\subsection{Researching Scale}

Landfill leachate was taken from Damai landfill site, Tancuong commune, Thainguyen city, Vietnam. Damai site have been operated since 1999 to treat solid waste for Thainguyen city and other towns. The source of landfill solid waste come from domestic and industrial activities, such as plastic bags, municipal waste, kitchen garbage, battery. So, the compound of leachate is very complex and is mixed young and old. In period of this research, leachate samples were taken from the pond between August and November 2011. It was kept in plastic cans and stored at $4{ }^{\circ} \mathrm{C}$ in the laboratory of Institute of Environmental Technology, Vietnam Academy Science and Technology before analysing and treating. The result shows the characteristics of landfill leachate from Damai site. The characteristics of landfill leachate from Damai site: $\mathrm{pH}$ : 7.5-8.3; COD: 2,1004,500 mg L ${ }^{-1}$, Color: 1,450-4,400 Pt-Co.

\subsection{Experiments 1: Pre-Treamtment By Coagulation-Coagulation Processes}

Coagulation was used to treat leachate in experiments with coagulants: PAC, $\left(\mathrm{Al}_{2}\left(\mathrm{SO}_{4}\right)_{3} \cdot 18 \mathrm{H}_{2} \mathrm{O}\right.$, $\mathrm{Fe}_{2}\left(\mathrm{SO}_{4}\right)_{3} .7 \mathrm{H}_{2} \mathrm{O}$ and $\mathrm{H}_{2} \mathrm{SO}_{4}, \mathrm{NaOH}$.

\subsection{Analytical Methods}

$\mathrm{pH}$ and COD were analyzed by Standard Methods (APHA, 2005). Color was analyzed by spectrum method with Pt-Co color at $420 \mathrm{~nm}$ (APHA, 2005).

\subsection{Experimental Equipment}

Coagulation experiments were performed in the Jartest aparatus (model: JLT6 Jar test/Flocclulator, made in Italy) equipped with 6 backers showed in Fig. 1.

\subsection{Experimental Methods}

Pre-treatment experiments of leachate were carried out with three types of coagulants: Polyaluminium Chloride (PAC), aluminum sulfate $\left(\mathrm{Al}_{2}(\mathrm{SO} 4)_{3} \cdot 18 \mathrm{H}_{2} \mathrm{O}\right)$ and ferric sulfate $\left(\mathrm{Fe}_{2}\left(\mathrm{SO}_{4}\right)_{3} .7 \mathrm{H}_{2} \mathrm{O}\right) .5 \mathrm{mg} \mathrm{L} \mathrm{L}^{-1}$ of coagulant auxiliary A110 (sodium acrylates Acrylamic copolime) was added to increase coagulation process.

The experiments were investigated the effects of concentration of coagulants on treatment efficiency, followed by the concentration of which will be suitably determined for coagulation process and advantage for the next stage.

The experiments were conducted at room temperature $\left(20 \pm 2^{\circ} \mathrm{C}\right)$. In each of the tests, coagulants (with calculated ratio) were added into a reaction beaker containing $500 \mathrm{~mL}$ of leachate. The concentration of coagulants were varied from $500 ; 1,000 ; 1,500 ; 2,000$; 3,$000 ; 4,000$ to $5,000 \mathrm{mg} \mathrm{L}^{-1}$. Quick phases took place in $3 \mathrm{~min}$ at a speed of 150 revolutions per minute and then added coagulants Auxiliary (A110) at the last minute of rapid stirring time. After that, stirring speed was reduced to 50 revolutions per min for $10 \mathrm{~min}$. After slow stirring process, samples were settled out from 30 to $60 \mathrm{~min}$.

\subsection{Experiments 2: Landfill Leachate Treatment by Ozonation Processes}

After coagulation, leachate was treated in the batch-type ozonation apparatus showed in Fig. 2, type reaction with working volume of 15 liters, consisting of a mica column with a heigh of $120 \mathrm{~cm}$ and internal diameter of $10 \mathrm{~cm}$. The pre-treated leachate sample was pumped into a reactor with volume of 5 liters. Ozone is generated by ozone generator (model: OR-15-C). It was purchased from Miyamoto Corporation, Japan. The capacity of ozone is generated $24 \mathrm{mg} \mathrm{h}^{-1}$ (with flow rate: $4 \mathrm{~L} \mathrm{~min}{ }^{-1}$ ). The air containing ozone was then pumped into the reactor with determining time period, air flow rate was $4 \mathrm{~L} \mathrm{~min}^{-1}$. 
Van Huu Tap and Trinh Van Tuyen / American Journal of Environmental Science 9 (6): 518-528, 2013

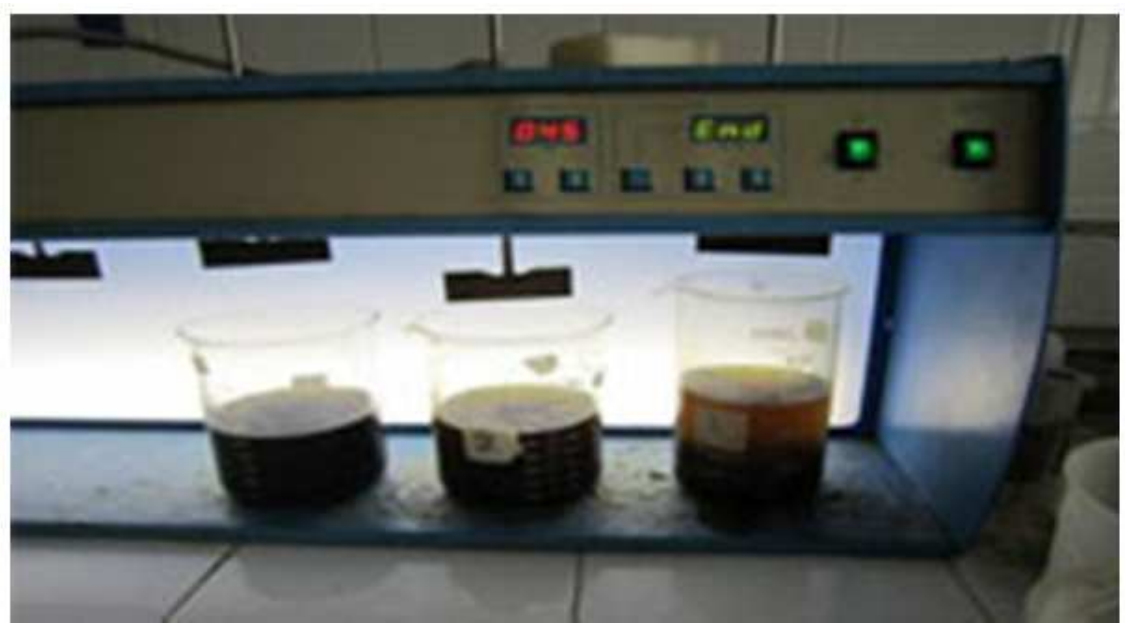

Fig. 1. Jar-test equipment

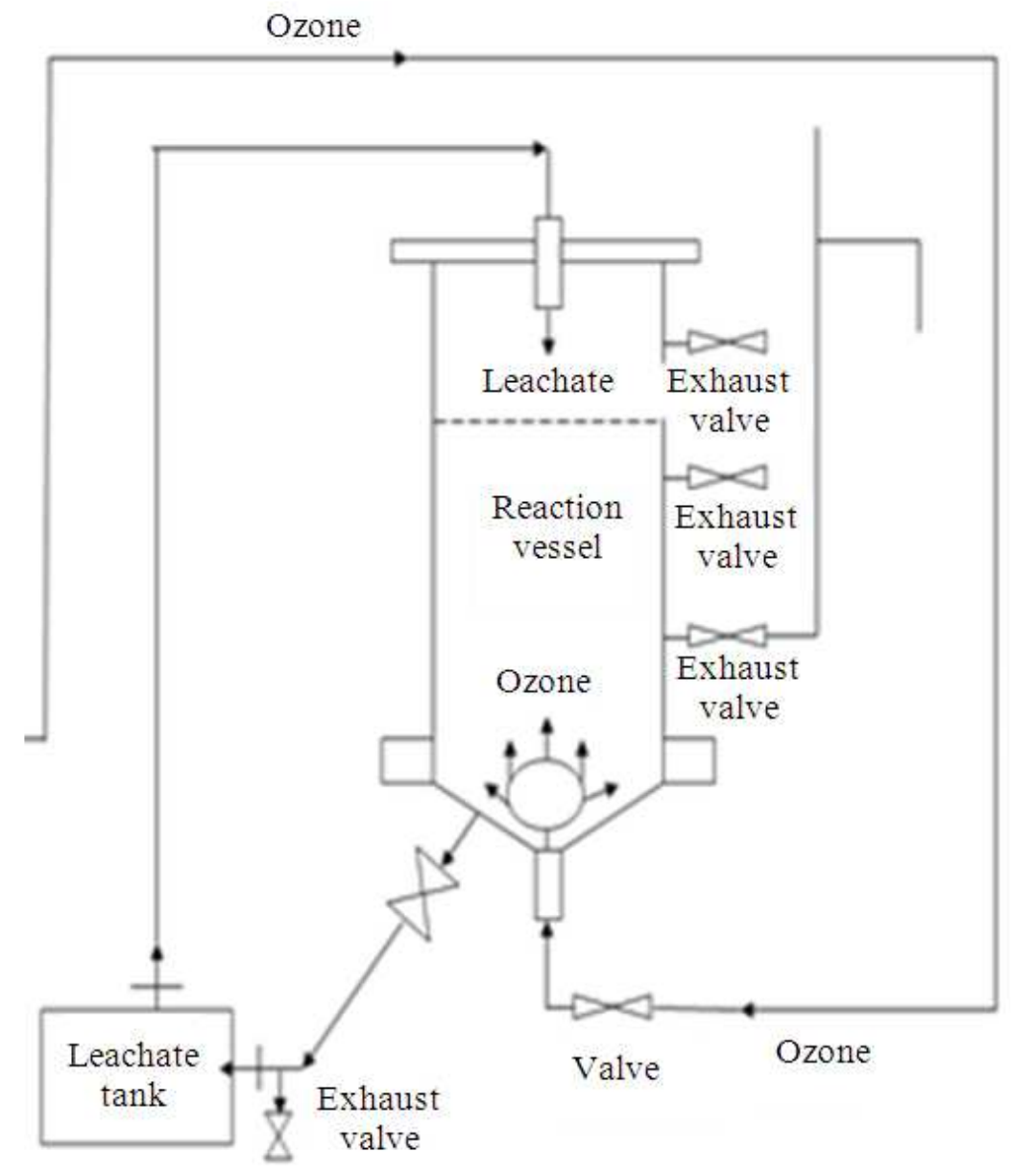

Fig. 2. Schematic of the ozonation apparatus 
The experiments were performed to determine the optimum of $\mathrm{pH}$, reaction time and the amount of COD. Initial $\mathrm{pH}$ was varied from $5,6,7,8,9$ to 10 by sulfuric acid and sodium hydroxide for landfill leachate. The reaction time was varied from 20,40 , $60,80,100$ to $120 \mathrm{~min}$. There are the change of the amount of COD from $3 ; 6 ; 9$ to $12 \mathrm{~kg}$. COD and color were then investigated to identify optimun of $\mathrm{pH}$, reaction time and the amount of COD.

\section{RESULTS}

$\mathrm{pH}$ value of leachate was not changed for coagulation, it is between 7 and 8 . The experiments were conducted with change of concentrations of coagulant of $500 \mathrm{mg} \mathrm{L}^{-1}$ to $5,000 \mathrm{mg} \mathrm{L}^{-1}$.

The effects of concentration coagulants on treatment efficiency are showed in Fig. 3. Figure 4 illustrates the effect of coagulants on color removal. The effect of $\mathrm{pH}$ on COD and color removal in treatment of leachate by ozonation process are presented in Fig. 5 and 6, respectively. Figure 8 and 9 inlustrate the change of COD and color by treating leachate after increasing time reaction. Effect of the amount of COD on COD and color removal are presented in Fig 11 and 12. The amount of dissolved ozone are showed in Fig. 7, 10 and 13.

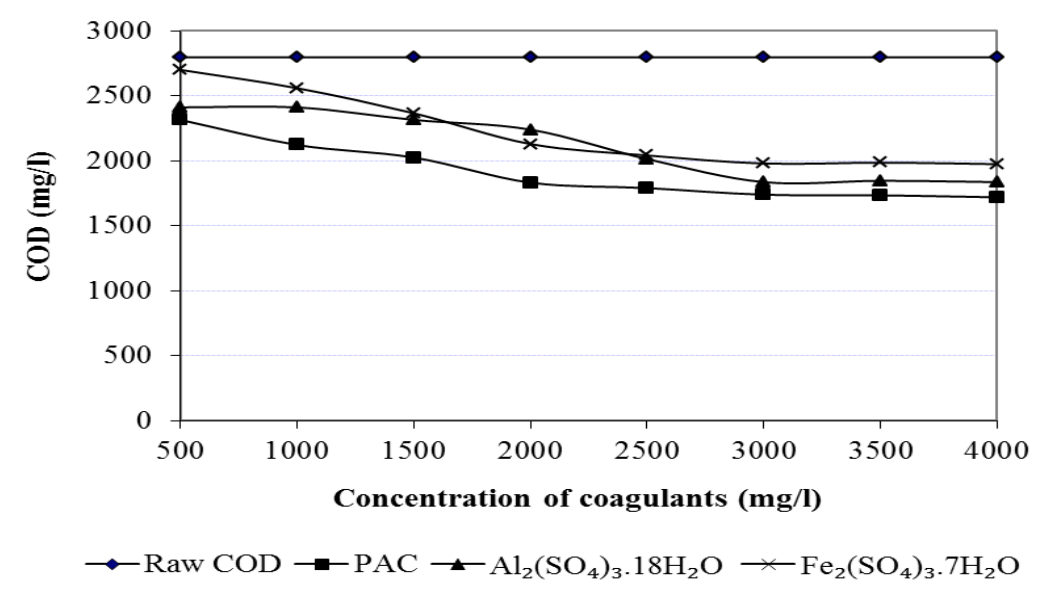

Fig. 3. Effect of concentration of coagulant on COD removal

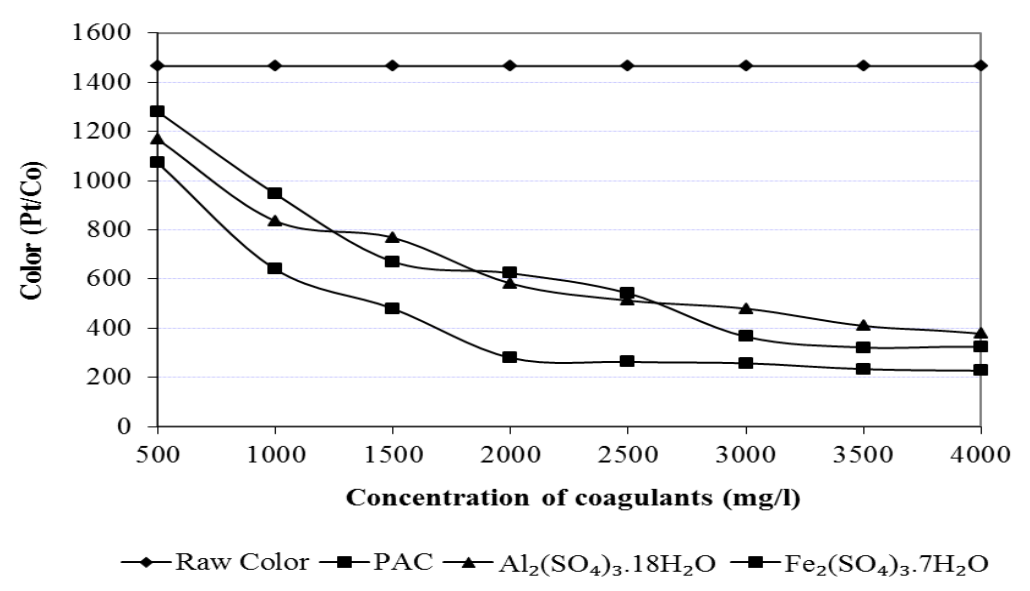

Fig. 4. Effect of concentration of coagulant on color removal 
Van Huu Tap and Trinh Van Tuyen / American Journal of Environmental Science 9 (6): 518-528, 2013

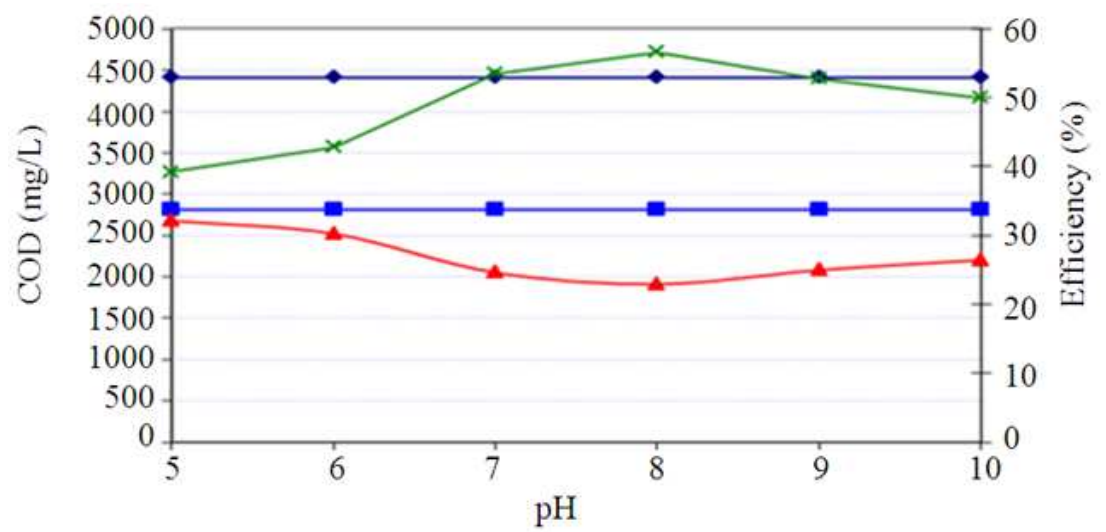

$\rightarrow$ Raw leachate $\rightarrow$-After coagulation $\rightarrow$ After ozonation $\rightarrow$ Effective

Fig. 5. The effect of $\mathrm{pH}$ of leachate on COD by ozonation process

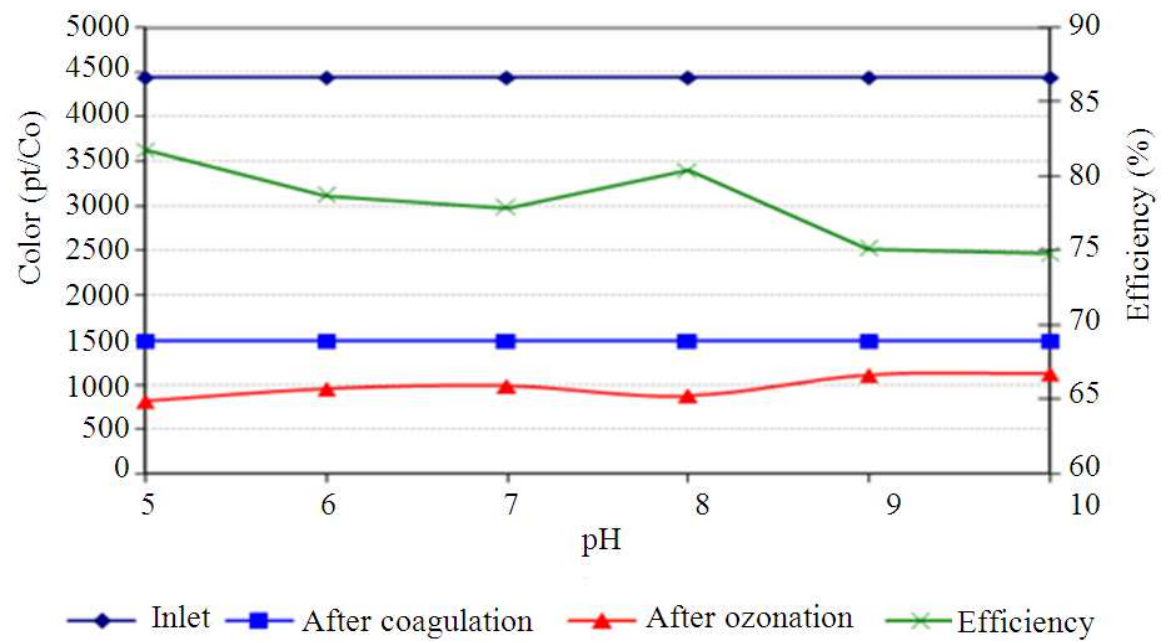

Fig. 6. Effect of $\mathrm{pH}$ of leachate on color by ozonation process

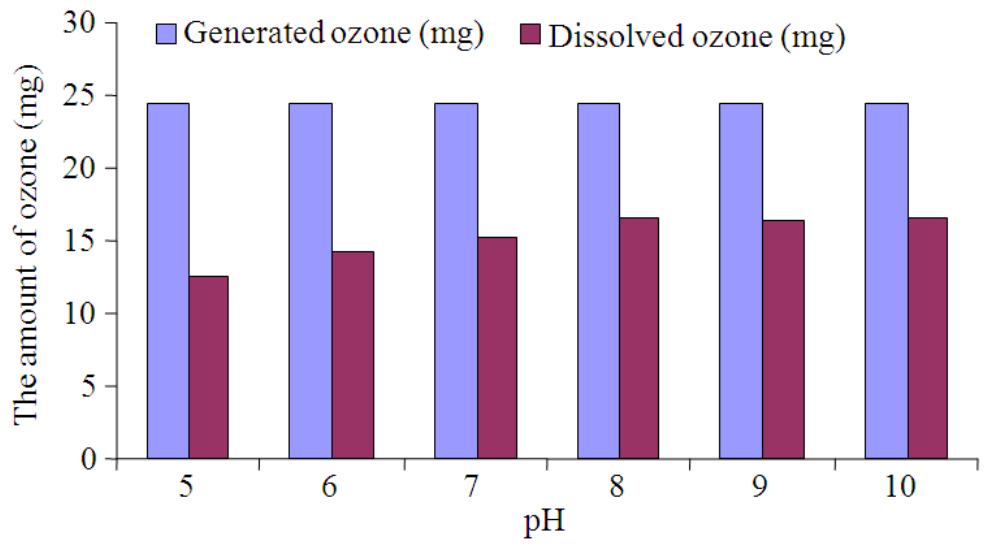

Fig. 7. The amount of dissolved ozone for experiment of $\mathrm{pH}$ change 
Van Huu Tap and Trinh Van Tuyen / American Journal of Environmental Science 9 (6): 518-528, 2013

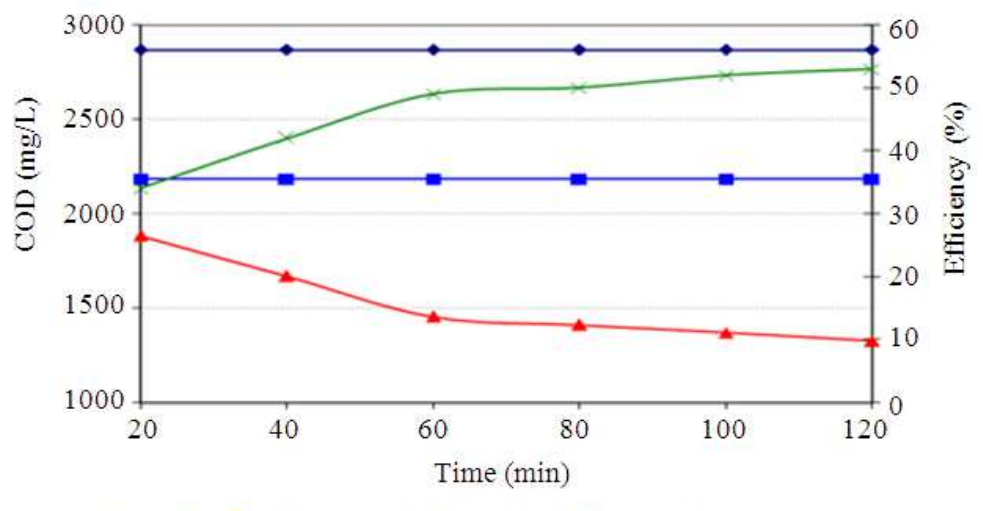

$\rightarrow-$ Inlet $\rightarrow-$ After coagulation $\longrightarrow$ After ozonation $\longrightarrow$ Efficiency

Fig. 8. The effect of reaction time of ozone and leachate on COD removal

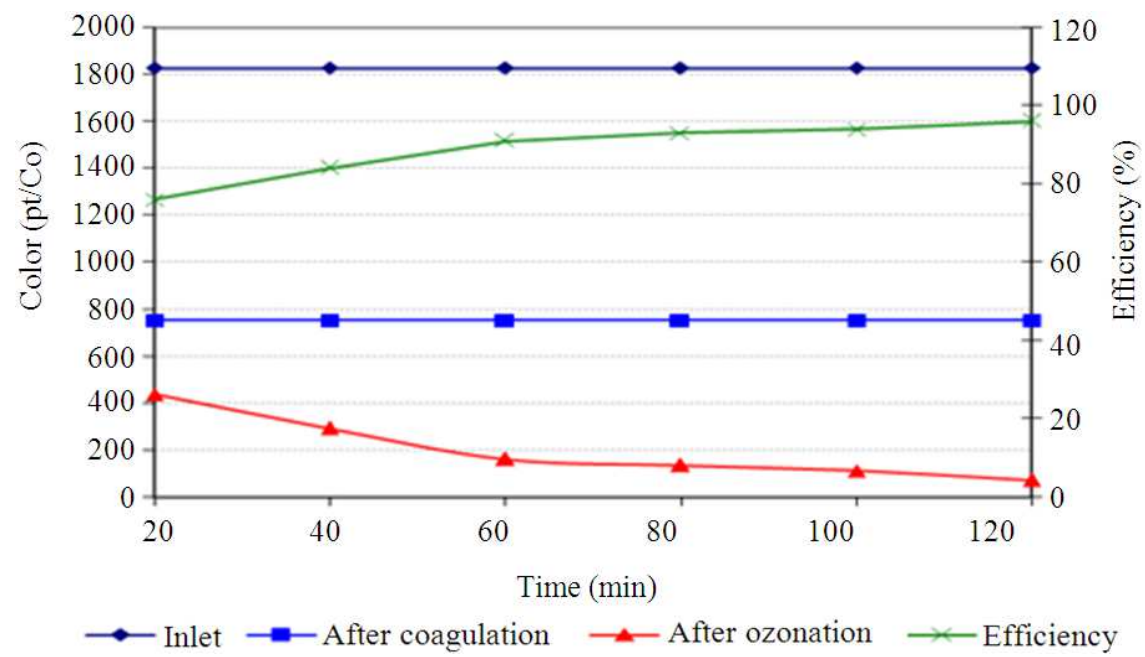

Fig. 9. The effect of reaction time of ozone and leachate on color removal

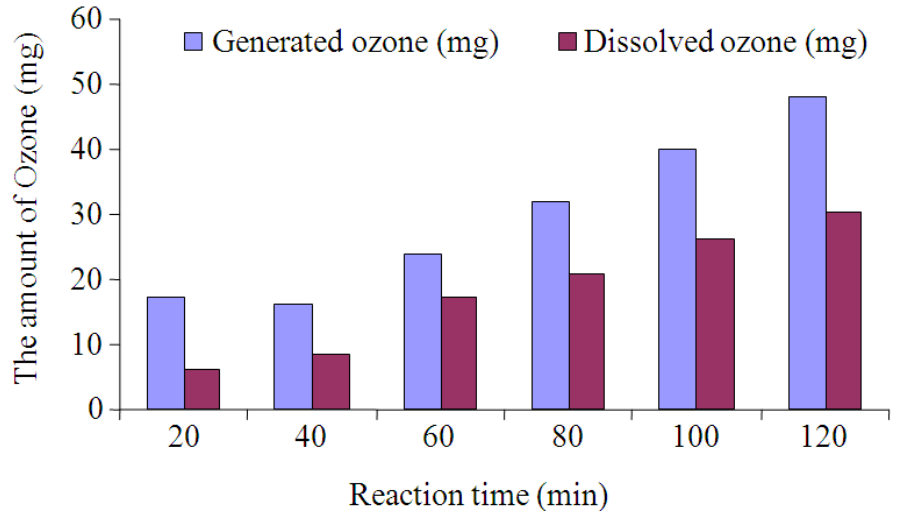

Fig 10. The amount of dissolved ozone for experiment of reaction time 
Van Huu Tap and Trinh Van Tuyen / American Journal of Environmental Science 9 (6): 518-528, 2013

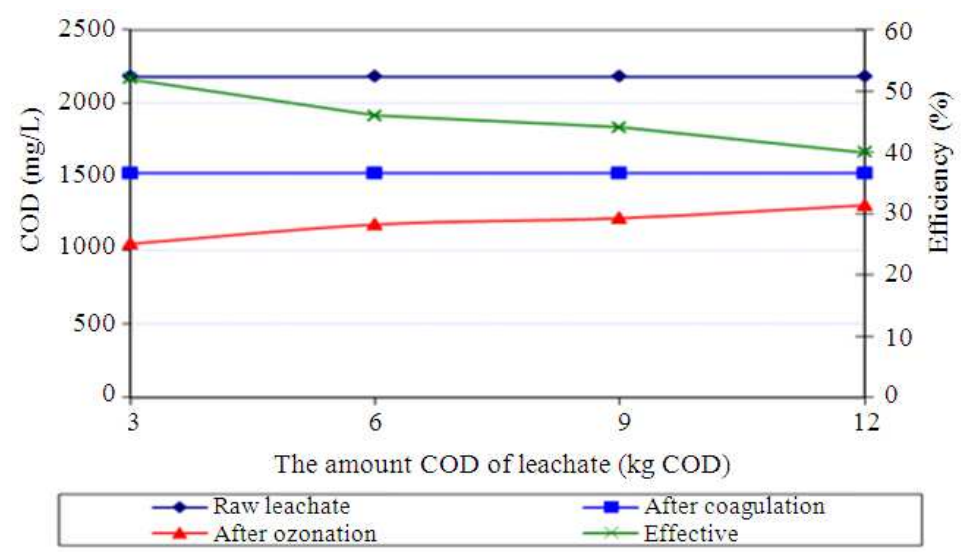

Fig. 11. The effect of the amount of COD on COD removal

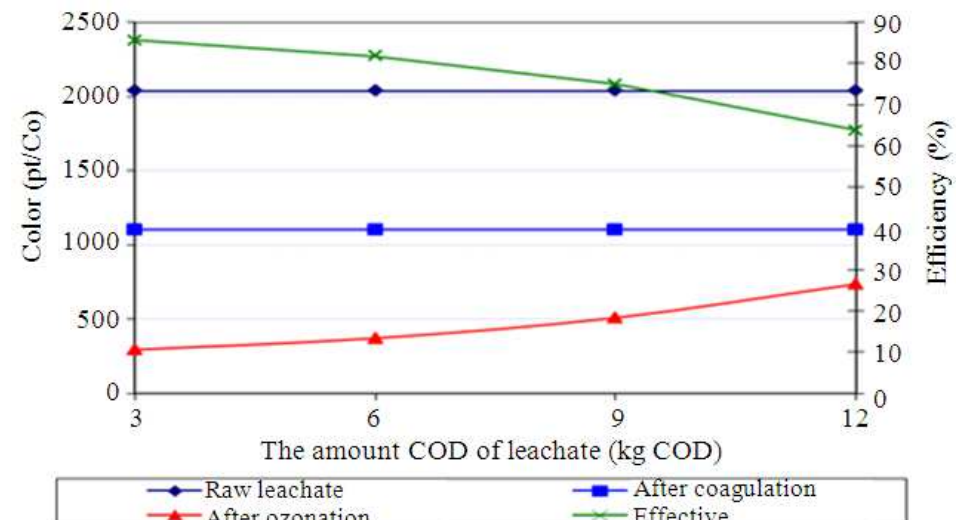

Fig. 12. Effect of the amount of COD on color removal

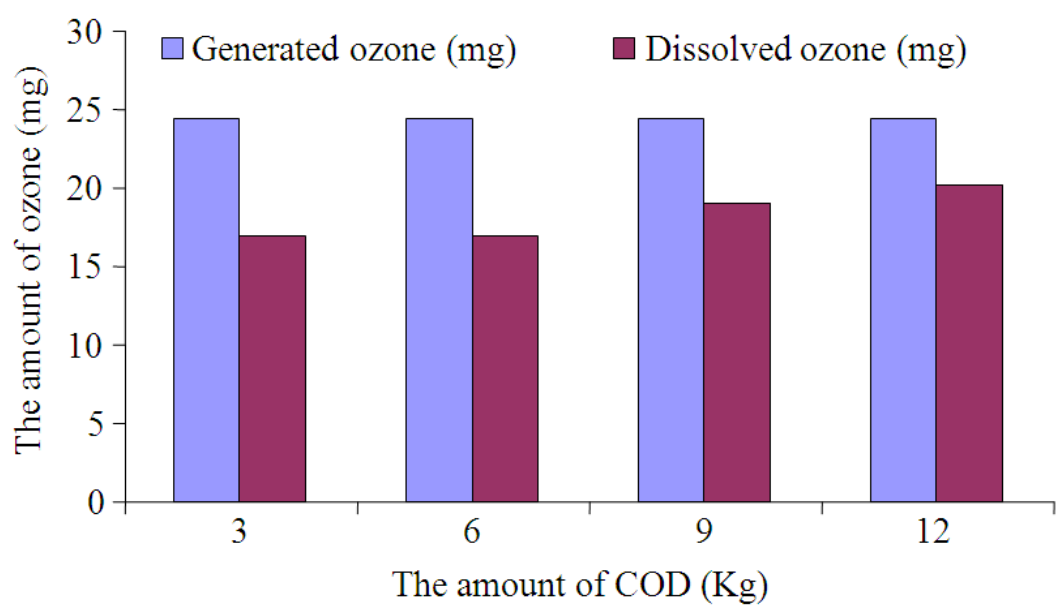

Fig. 13. The amount of dissolved ozone for experiment of the amount of COD 


\section{DISCUSSION}

\subsection{Pre-Treatment by Coagulation}

\subsubsection{The Effect of Coagulants' Concentration on COD Removal}

Figure 3 showed that performance of COD concentration removal increased with increasing concentration of coagulants (performance with PAC: 17$38 \%, \mathrm{Al}_{2}\left(\mathrm{SO}_{4}\right)_{3} .18 \mathrm{H}_{2} \mathrm{O}: 14-34 \%$ and $\mathrm{Fe}_{2}\left(\mathrm{SO}_{4}\right)_{3} .7 \mathrm{H}_{2} \mathrm{O}: 3-$ $30 \%$ ). The COD concentration decreased significantly after coagulation at concentrations from $1,500 \mathrm{mg} \mathrm{L}^{-1}$. The COD concentration decreased from $2,798 \mathrm{mg} \mathrm{L}^{-1}$ to $1,740 \mathrm{mg} \mathrm{L}^{-1}$ when coagulants reached from 3,000 $\mathrm{mg} \mathrm{L}^{-1}$ or higher. Reaction might be saturated. The PAC was found to give higher efficiency of removal of organic matters than others with its concentration from 500 to $3,000 \mathrm{mg} \mathrm{L}^{-1}$. After that, it was not increased even with increasing concentration of coagulant. However, COD removal reduced when increasing concentration of ferric sulfate.

\subsubsection{Effect of Concentration on Color Removal}

Performance of color removal by using coagulation process increased quickly with increasing their concentrations from 500 to $2,000 \mathrm{mgL}^{-1}$. The result is showed in Fig. 4. It was increased mostly in amounts of 1,000 to $2,000 \mathrm{mg} \mathrm{L}^{-1}$ and then remains constant. PAC was one of the three chemicals that had the highest performance of coagulation for these experiments. The efficiency of color removal by $\mathrm{Al}_{2}\left(\mathrm{SO}_{4}\right)_{3} \cdot 18 \mathrm{H}_{2} \mathrm{O}$ is similar to $\mathrm{Fe}_{2}\left(\mathrm{SO}_{4}\right)_{3} \cdot 7 \mathrm{H}_{2} \mathrm{O}$. Color went down quickly from 1,512 to $280(81 \%)$ at PAC concentration of 2,000 $\mathrm{mg}^{-1}$ it then is not significantly reduced. It decreased down to 480 and 360 (68 and $76 \%$ respectively) at $3,000 \mathrm{mg} \mathrm{L}^{-1}$ of $\mathrm{Al}_{2}\left(\mathrm{SO}_{4}\right)_{3} \cdot 18 \mathrm{H}_{2} \mathrm{O}$ and $\mathrm{Fe}_{2}\left(\mathrm{SO}_{4}\right)_{3} \cdot 7 \mathrm{H}_{2} \mathrm{O}$, respectively. However, it was still high after coagulation. Because persistent organics of leachate such as humic, benzen and phenol affect highly on pretipication and adsorption of coagulants, their concentrations were required higher than other that of wastewater. The $\mathrm{pH}$ of leachate samples had decreased after treatment by coagulation because cations of $\mathrm{Al}^{3+}$ and $\mathrm{Fe}^{3+}$ have acidic characters.

The effect of coagulation process with ferrous sulfate on COD, apparent color and turbidity was researched for the pre-treatment of mature landfill leachate of the Pulau Burung Sanitary Landfill, Malaysia (Abbas et al., 2009). The results showed that at the optimum setting for coagulant dosage was $10 \mathrm{~g} \mathrm{~L}^{-1}$ and $\mathrm{pH} 11.7$, resulted in maximum of (22\%) in COD, (42\%) in apparent color and $(31 \%)$ in turbidity. The coagulation of leachate samples was accomplished by addition of different coagulants including ferric chloride, aluminum sulphate, ferrous sulphate and poly-aluminum chloride in various coagulant and $\mathrm{pH}$ values, respectively (Jamali et al., 2009). Results of these tests showed that among traditional coagulants the best coagulant for treatment of the leachate is ferric chloride in combination with an anionic polyelectrolyte (Magnafloc LT25). Maximum COD and color removal rates for 41 and $70 \%$ had been achieved by addition of $2.5 \mathrm{~g} 1 \mathrm{G}$ of ferric chloride as $\mathrm{Fe}$. These results were slighly difference with our findings because landfill leachate in Vietnam is more complex than that of previous studies. Landfill sites consist of municipal and industrial solid waste as well as hospital solid waste without classifying from sources. So leachate characteristics are very complex, including high organic compounds (humic and fulvic acid, lignin, phenol and macromolecular compound...) and high toxic compounds from solid waste of industry and hospital.

The objective of pre-treatment is COD and color removals of about $30 \%$, therefore, the PAC with $1,500 \mathrm{mg}$ $\mathrm{L}^{-1}$ was suitable for this research with $\mathrm{pH}$ value from 7 to 8 . Because the cost of $\mathrm{Fe}_{2}\left(\mathrm{SO}_{4}\right)_{3} .8 \mathrm{H}_{2} \mathrm{O}$ is much higher than that of PAC, it is not to choose for this research.

\subsection{Treatment of Leachate by Ozonation Process}

\subsubsection{Determination of Optimal pH Range for Ozonation Process}

Before ozonation process, the leachate was treated by coagulation with PAC without adjusting $\mathrm{pH}$ (after adding coagulants, $\mathrm{pH}$ dropped from 8.3 to 7.75 ) and with concentration of $1,500 \mathrm{mg} \mathrm{L}^{-1}$.

\subsubsection{Effects of $\mathrm{pH}$ of Leachate on COD Removal by Ozonation Process}

The ozonation process was performed as follows: Input airflow at $4 \mathrm{~L} \mathrm{~min}^{-1}$, the reaction time was $60 \mathrm{~min}$ and not change for all experiments of $\mathrm{pH}$ effect; 5 liters of leachate for each experiment sample. The gas stream was fed to the bottom of the batch. Leachate was pumped from the top of the batch (Fig. 2). The experiments were done with $\mathrm{pH}$ value varied from 5 to 10 .

The results of experiments to determine the influence of $\mathrm{pH}$ of leachate was represented in Fig. 5: With $\mathrm{pH}$ range from 5 to 10 , optimal performance was achieved at 
$\mathrm{pH}$ value $\approx 8$ (reaching $57 \%$, COD decreased from 4,408 $\mathrm{mg} \mathrm{L}^{-1}$ to $\left.1,912 \mathrm{mg} \mathrm{L}^{-1}\right)$.

\subsubsection{Effect of $\mathrm{pH}$ of Leachate on Color Removal by Ozonation Process}

Figure 6 showed that efficiency of color removal was similar when changing the $\mathrm{pH}$ of the leachate. It was generally very high (from $75-85 \%$ ). It was higher (78$82 \%$ ) at $\mathrm{pH}$ from 5 to 8 than that from 9 to 10 . In this study, when $\mathrm{pH}$ of leachate was adjusted to 5 there was precipitation before coagulation because some organic matters of leachate, such as humuc and fulvic acid, lignin and phenol were precipited at low $\mathrm{pH}$ condition, so color removal increase and reached $82 \%$ after ozonation process. Therefore, the optimal efficiencies of COD and color removals were achieved at $\mathrm{pH}$ 8. $\mathrm{pH}$ value of leachate was set to 8 in the next stage.

The amount of ozone was consumed for each experiment was showed on below table (the concentration of dissolved ozone was measured by the indigo method (APHA, 2005) method No. 4500-- $\mathrm{O}_{3}$.

The amount of ozone was dissolved about $70 \%$ in leachate for all $\mathrm{pH}$ condition. From Fig. 7 also showed that the amount of generated ozone was low $(24.48 \mathrm{mg})$ for $60 \mathrm{~min}$. However, it was not reacted completely with organic matters of leachate because ozone is difficult to dissolve in water and wastewater.

Under acidic condition, organic compounds were oxidised directly by molecular ozone. The direct oxidition $\left(\mathrm{M}+\mathrm{O}_{3}\right)$ of organic compound by ozone is a selective reaction with slow reaction rates, typically being in the rang of $\mathrm{k}_{\mathrm{D}}=1.0-10^{3} \mathrm{M}^{-1} \mathrm{~s}^{-1}$ (Gottschalk et al., 2000). Surface waters $(\mathrm{pH} \approx 7)$ both pathways-direct and indirect-can be of importance (Hoigje, 1983). The result of this research was similar to that of Staehlin and Hoigié's research. In high $\mathrm{pH}$ (alkality condition), the decay of ozone to form secondary oxidants sach as hydroxyl radicals $\left(\mathrm{OH}^{\bullet}\right)$ :

$$
\mathrm{O}_{3}+\mathrm{H}_{2} \mathrm{O} \rightarrow 2 \mathrm{HO}^{\bullet}+\mathrm{O}_{2}
$$

Oxidation of organic compounds by hydroxyl free radicals produced during the decomposition of ozone. Thus, under conditions favoring hydroxyl free radical production, the hydroxyl oxidation starts to dominate. However, $\mathrm{OH}^{\bullet}$ can be destroyed by anions of $\mathrm{Cl}^{-}$, $\mathrm{CO}_{3}{ }^{2-}, \mathrm{HCO}_{3}{ }^{-}$of leachate in Vietnam:

$$
\begin{aligned}
\mathrm{OH}^{\bullet}+\mathrm{CO}_{3}{ }^{2-} & \rightarrow \mathrm{CO}_{3}{ }^{\bullet-}+\mathrm{HO}^{-} \\
\mathrm{OH}^{\bullet}+\mathrm{HCO}_{3}^{-} & \rightarrow \mathrm{HCO}_{3}{ }^{-}+\mathrm{OH}^{-} \\
\mathrm{OH}^{\bullet}+\mathrm{Cl}^{-} & \rightarrow \mathrm{ClOH}^{\bullet-}
\end{aligned}
$$

These inhibitors often terminate the chain reaction and ihibit ozone decay (Gottschalk et al., 2000). Therefore, in this research, the efficiency of COD and color removal decreased with high $\mathrm{pH}$ of leachate. The result of this research is different to several authors such as Ratanatamskul and and Auesuntrachun (2009), the optimun of $\mathrm{pH}$ was achieved at 11; (Aken et al., 2011), the $\mathrm{pH}$ value of 9 achieved. However, the result of this research was similar to Hien (2012) research on leachate in Vietnam, 2012, with $\mathrm{pH}$ of 7.5 was determined at the highest efficiency.

\subsubsection{Determination of Optimal Time of Reaction}

The experiments below followed these selected parameters: $\mathrm{pH}=8$, airflow to $4 \mathrm{~L} \mathrm{~min}^{-1}$. Reaction time was ranging from 20-120 min.

\subsubsection{Effect of Reaction Time on COD Removal}

The results of experiments to determine the reaction time of leachate was represented in Fig. 8: COD of raw leachate was $2,868 \mathrm{mg} \mathrm{L}^{-1}$ but it decreased to $2,183 \mathrm{mg}$ $\mathrm{L}^{-1}$ with efficiency of $24 \%$ after coagulation by PAC. Ozonation experiments showed significant reduction in COD after $40 \mathrm{~min}$ and the highest decline is after $60 \mathrm{~min}$, reduced to $1,455 \mathrm{mg} \mathrm{L}^{-1}$ (removing $49 \% \mathrm{COD}$ ). Then efficiency did not increase significantly when reaction time was increased. The cause of this can be explained that the reaction between ozone and organics of leachate reaches saturated rate.

\subsubsection{Effect of Reaction Time on Color Removal}

Similar to COD removal, color removal efficiency was high after ozonation process, raw landfill leachate was gray but it changed to black green after coagulation. It is presented in Fig. 9. Ozonation was conducted to remove landfill leachate from $20 \mathrm{~min}$ to $120 \mathrm{~min}$. It could be seen that leachate changed from black green to brown after $20 \mathrm{~min}$ of reaction with the color was 438 Pt-Co (efficiency of 76\%), then yellow in $40 \mathrm{~min}$ (the color: 294 Pt-Co with efficiency of 84\%). After $60 \mathrm{~min}$ it switched to white with $93 \%$ of color removal, efficiency of color removal was $97 \%$ after $120 \mathrm{~min}$.

The amount of ozone was consumed for each experiment of effect of reaction time is showed in the Fig. 10.

The amount of dissolved ozone increased with time from 20 to $80 \mathrm{~min}$. It slowly went up when reaction time rising. The amount of ozone that was not reacted increase with time. As a result, optimal reaction time was 
identified after $60 \mathrm{~min}$ for this research. The cause can be explained that reaction of $\mathrm{OH}^{\bullet}$ and $\mathrm{O}_{3}$ with organic matters in leachate might have reached saturation levels. In addition, $\mathrm{OH}^{\bullet}$ was also decayed by several anions $\mathrm{Cl}^{-}$, $\mathrm{HCO}_{3}^{-} \ldots$ of the leachate. Thus, the efficiency of COD and color removal and dissolved ozone in leachate slightly increased with rised reaction time. The cost can be higher when increasing reaction time. So, reaction time of $60 \mathrm{~min}$ is suitable for this research.

\subsubsection{Determination of Optimum of the Amount of COD of Leachate}

In these experiments, the amount of COD of leachate was changed to the test. The experiments were conducted with leachate after coagulation as follows: Airflow at $4 \mathrm{~L} \mathrm{~min}{ }^{-1}$, reaction time: $60 \mathrm{~min}$ with ozone concentrations generated at $24.48 \mathrm{mg} \mathrm{L}^{-1}$ air. The amount of COD of the leachate test was 3, 6, 9 and $12 \mathrm{~kg}$ COD.

\subsubsection{Effect of the Amount of COD of Leachate on COD Removal}

Figure 11 showed that the COD concentration of raw leachate was $2,180 \mathrm{mg} \mathrm{L}^{-1}$, after coagulation, it decreased to $1,526 \mathrm{mg} \mathrm{L}^{-1}$ with efficiency of $30 \%$. Ozonation processes were conducted with the amount of COD of leachate was 3, 6, 9 and $12 \mathrm{~kg}$. After these processes, the highest efficiency of COD removal was equivalent to $52 \%$ with $\mathrm{COD}=1,046 \mathrm{mg} \mathrm{L}^{-1}$ at $3 \mathrm{~kg}$ COD. Then increasing the amount of COD to $6,9,12 \mathrm{~kg}$, the COD removal efficiency decreased gradually and reduced to $40 \%$ at $12 \mathrm{~kg}$.

\subsubsection{Effect of the Amount of COD on Color Removal}

The efficiency of color was also similar to COD removal showed in Fig. 12. It decreased with increasing the amount of COD. It reached the highest value of $86 \%$ at $3 \mathrm{~kg}$ of COD. Then the increasing the amount of COD, efficiency decreased because when increasing concentrations of $\mathrm{COD}$, the mass of $\mathrm{O}_{3}$ reduced, so efficiency went down.

The amount of dissolved ozone in the leachate is showed in Fig. 13. It was slightly increased with increased the amount of COD from 3 to $10 \mathrm{~kg}$. Because the amount of organic matters of batch is rised with increased the amount of COD, so, more ozone dissolved in the leachate. However, dosage of ozone per the amount of COD decreased. Therefore, the amount of COD of leachate was increased the efficiency of COD and color removal decreaased.

\section{CONLUSION}

Leachate is difficult to handle, using only one method will not achieve good results, so there should be several stages with appropriate treatment methods. In this research, tests of coagulation of leachate showed that after processing with this method, leachate still met standards to discharge. Therefore, during this experiment, the coagulation was considered the first stage of processes. From the experiments, the parameters suitable for the first phase of leachate treatment have been determined: PAC of 1,500 $\mathrm{mg} \mathrm{L}^{-1}$. After ozonation process, the optimal parameters have also been determined: $\mathrm{pH}=8$, reaction time: $60 \mathrm{~min}$ and the amount of COD: $3 \mathrm{~kg}$. The process of combination of coagulation-coagulation and ozonation achieved high efficiencies: COD removal efficiency: $52 \%$, color: $86 \%$, respectively. In addition, with high persistent and toxic organic matters of leachate in Vietnam, ozonation process can be used to remove no-biodegradable organic compounds before bio-treatment is necessary.

\section{REFERENCES}

Abbas, F. M. Alkarkhi, Talebi Amir, Norli Ismail, T.T. Teng, 2009. Optimization of coagulation process for landfill leachate pre-treatment using Response Surface Methodology (RSM). J. Sustainable Dev., 2: 159-167.

Aken, P.V., L. Nico, D. Jan, L. Sven and L. Jan, 2011. Comparison of different oxidation methods for recalcitrance removal of landfill leachate. J. Ozone: Sci. Eng., 33: 294-300. DOI: 10.1080/01919512.2011.583170

APHA, 2005. Standard methods for the examination of water and wastewater. Proceedings of the 19th American Public Health Association, (APHA' 05), Washington DC.

Gottschalk, C., J. A. Libra and A. Saupe, 2000. Ozonation of Water and Wastewater, A practical guide to understanding ozone and its application. WILEY-VCH verlag GmbH, D-69469 Weinheim, Federal republic of Germany.

Hien, H.T., 2012. Treatment of landfill leachate by advance oxidation process: Combining $\mathrm{O}_{3}$ and UV. Master Thesis, School of Environmental Science and Technology, Hanoi University of Science and Technology, Vietnam.

Hoigje, J.S., 1983. Reaktions mechanismus und Kinetik des ozonzerfals in Wasser in gegenwart organischer Staffe. Vom Wasser, 61: 337-348. 
Jamali., H.A., A.H. Mahvi, R. Nabizadeh, F. Vaezi and G.A. Omrani, 2009. Combination of coagulationflocculation and ozonation processes for treatment of partially stabilized landfill leachate of Tehran. World Applied Sci. J., 5: 9-15.

Malato, S., G. Mascolo, D. Cassano, A. Zapata and G. Brunetti et al., 2011. Comparison of several combined/integrated biological-AOPs setups for the treatment of municipal landfill leachate: Minimization of operating costs and effluent toxicity. Chem. Eng. J., 172: 250- 257. DOI: 10.1016/j.cej.2011.05.098

Ratanatamskul, C. and P. Auesuntrachun, 2009. Removal of COD and colour from old-landfill leachate by advanced oxidation processes. Int. J. Environ. Waste Manage., 4: 470-480. 10.1504/IJEWM.2009.02741
Rosario, O., S. Cortez, P. Teixeira, M. Mota, 2011. Evaluation of Fenton and ozone-based advanced oxidation processes as mature landfill leachate pretreatments. J. Environ. Manage., 92: 749-755. DOI: 10.1016/j.jenvman.2010.10.035

Tung, T.Q., L.V. Tuan, N.T.K. Tuyet and P.K. Lieu, 2009. Treatment of leachate by UV-fenton in intermittent reaction batch. J. Sci. Hue Univ., 53: 165-175.

Zhou, S., H.S. Li, Y. Sun, P. Feng, J. Li, 2009. Advanced treatment of landfill leachate by a new combination process in afull-scale plant. J. Hazard. Mater., 172: 408-415. 